Article

\title{
Online Learning Tools in the Era of m-Learning: Utility and Attitudes in Accounting College Students
}

\author{
Teresa C. Herrador-Alcaide ${ }^{1, *}$, Montserrat Hernández-Solís ${ }^{1}$ and J. Fortunato Hontoria ${ }^{2}$ \\ 1 Department of Business Economics and Accounting, National Distance Education University (UNED), \\ 28040 Madrid, Spain; montserrath@cee.uned.es \\ 2 National Distance Education University (UNED) (Madrid Sur-Tutor in Computing Teaching Area), \\ 28935 Móstoles, Madrid, Spain; joshontoria@madridsur.uned.es \\ * Correspondence: therrador@cee.uned.es; Tel.: +34-91-3986368
}

Received: 21 May 2020; Accepted: 22 June 2020; Published: 24 June 2020

\begin{abstract}
Learning in the Era of Mobile means an expansion in the range of learning tools, which are much more accessible thanks to the use of mobile devices. The greater possibilities of applying online tools for learning do not eliminate problems related to distance learning, such as personal factors related to attitude and student's perception in virtual learning environments. It is necessary to consider whether the mere application of online tools in m-learning is enough or whether the context and the way in which online learning tools are applied are what is really important, even more so when the program is directed towards students using a distance learning system. Seen from this point of view, the utility of online tools is a key factor for successful learning. Furthermore, it is known that the personal attitude can affect the student's perception about different aspects of learning, such as the perceived utility of the tools online. Considering the above arguments, the objective of this research is to measure the perceived utility of online learning tools by university students in a teaching environment accessible by mobile devices. Likewise, as a complementary objective to the measurement of perceived utility, the explanatory variables that could cause some effect on the perceived utility were analyzed. The analysis of explanatory variables is focused on personal attitudes, such as attitude towards accounting or the perceived role of the teacher. The data were collected through a questionnaire. Scoring indicators were applied to quantify the scores of university students for each variable. The analysis showed that mature students in a distance education program in Accounting assign high value to online tools and give a high score to their own attitude towards Accounting and the teacher's role in virtual learning. Regression analysis indicates that about $34 \%$ of the perceived utility of online tools could be explained by their positive attitude towards Accounting and by the role of the teacher in m-learning. The identification of explanatory variables of perceived utility of online tools could improve the design and adaptation of the virtual environment, according to personal needs of college students.
\end{abstract}

Keywords: m-learning; online learning tools; perceived utility; attitude towards Accounting; teacher's role

\section{Introduction}

Modern learning environments are based on the application of information and communication technologies (ICT), as an instrument for transmitting knowledge. Nowadays, online tools in learning environments have increased due to the widespread use of mobile devices and the development of telecommunication services. Social changing expanded the use of online learning tools that have traditionally been linked to distance learning, such as videoconferences, support classes through chats or forums, online tests, remote laboratories, or work groups via the web. These tools are 
implemented, as consequence of the development of own technology by incorporating a set of tools that already exist on the market (such as Meeting Burner, Tiny Chat, Classroom for blended learning, etc.). This technology facilitates the so-called "mobile learning" (m-learning). M-learning is understood as an electronic learning and teaching supported model by mobile devices. The distinctive features of mobile devices, such as constant communication and real-time access, are what can enhance certain pedagogies, such as self-directed learning [1], which are desirable for lifelong learning. The terminology of m-learning supposes the integration of mobile computing devices within teaching and learning, being the teaching professionals themselves who must analyze the characteristics and attributes for the successful m-learning [2]. It is teaching and training methodology that uses state-of-the-art mobile devices (Smartphones, tablets, I-pad, and others) as a means of transmitting knowledge in educational settings. The definition provided in [2] is the framework of m-learning in our teaching-learning process, where the tools applied to the virtual environment are accessible from mobile devices, both for students and teachers. Also consider that this definition implies that it is in fact a compliance with the three essential aspects of m-learning pointed out by [1]: Mobility, availability, and portability of learning process. The origin of teaching through electronic devices dates from the 19th century [3,4], thereby m-learning could be misinterpreted as a form of update e-learning but using new and more modern mobile devices. However, the current conception implies transformation in the methodologies to be applied, taking the attitudes linked to learning through mobile devices into account.

Mobile computing devices can provide educational opportunities [5,6], improving the learning process due to better interaction [7] and nowadays m-learning is practically identified with distance learning due to their mutual synergy [8]. When distance learning is carried out within an official university program, a distance teaching institution is guaranteeing the integration of online learning tools in a virtual learning environment (VLE). Usually, a VLE is specifically made for the teaching objectives, according to the university's methodology. The VLE must consider the personal characteristics of students in the program, adapting the best possible combination of online learning tools in the present context of m-learning. The design of VLE for mature students must take student's learning difficulties into account, such as lower technological aptitudes linked to older age students, family obligations, and less availability due to the fact that they are generally part-time students. Aspects, features, and advantages of m-learning (see Figure 1) support the utility of online tools for learning in the Era of Mobile.

Despite the variety of ICT for the generation of virtual learning environments (VLE) and their advantages, these new teaching tools also present problems. ICT causes rapid changes in the teaching way, such as the communication channel, the technological training, economic resources, etc. In addition, specific psychological aspects of the teacher and the learner must also be considered, such as community feeling versus isolation feeling. The feeling of belonging to a group or community diminishes the feeling of frustration or isolation due to the lack of physical contact with peers and teachers. To address this problem, the teacher should reduce the physical and psychological distance, supplying it with what is called transactional presence [9] (by knowing that there is someone on the other side of the mobile device). This argument justifies the extended acceptation of video in m-learning, by providing the positive effect due to the visualization of the teacher's image [10]. The analysis of the first virtual communities has already highlighted the importance of knowing students for the adequate design of positive virtual environments [11,12]. Recent research revealed the need to identify the requirements and difficulties of students in order to improve the learning environment [13]. Several research papers have shown evidence that using ICT as teaching tools could increase students' engagement [14] and teacher's role [15], because these tools could improve self-directed learning [16,17]. In this way, ICT tools have extended the meaning of lifelong learning and have provided new learning opportunities [18]. Some authors have shown that the mere presence of technological tools is not enough, with the context that they are applied in and the way in which they are used being more important for learning $[1,19]$. Educational technology must be combined with 
the use of instructional methods and work formats suitable for learning and teaching in technological environments [20].

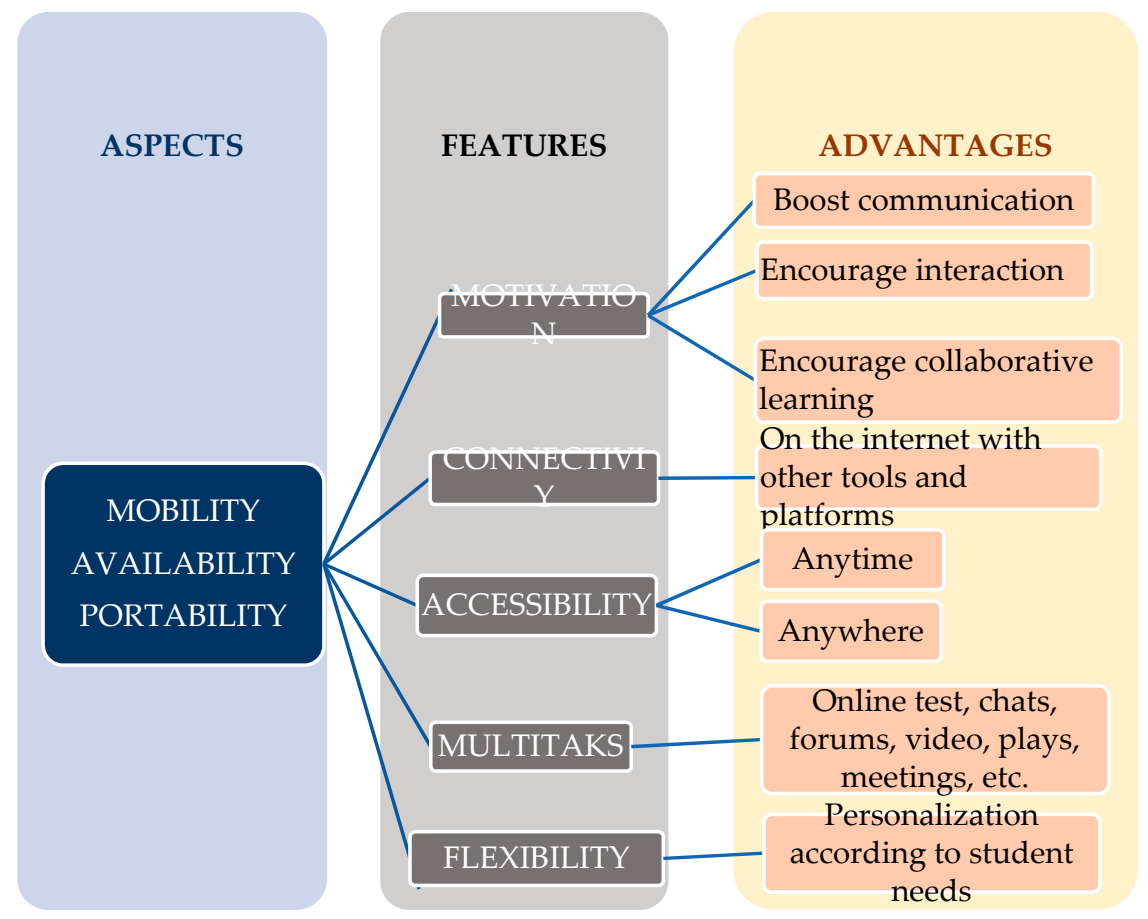

Figure 1. Aspects, features, and advantages of m-learning. Notes: 3 aspects of m-learning; 5 features of m-learning; 9 advantages for the prior features.

Within heutagogy, which can be understood as adult education (mature students), lifelong education is considered necessary for social sustainability and, as indicated by UNESCO [21], that promotes equal opportunities within communities, especially for workers. The use of appropriate tools and approaches can provide positive results in continuous learning and make virtual learning just as effective as permanent m-learning [22]. Studies related to the use of m-learning in educational institutions examine student's attitude towards the use and implementation of m-learning techniques for the sustainability of learning, with special emphasis on the importance of m-learning design [23].

A problem for a sustainable virtual education is the fact that teachers meet technologically native students, who naturally expect the application of ICT in all aspects of their lives, including learning. However, teachers doubt the effectiveness of the use of technologies and m-learning as the main teaching support [24], due to a big generational gap. It has been shown that teacher training in the use of new methodologies based on ICT in higher education, such as the educational video, can promote sustainable educational practices [25]. Teachers must promote positive attitudes in students [26]. Studies related to the use of ICT-based learning, such as cloud learning, show that it is necessary to understand the student's attitude towards the sustainable use of learning, since the student's attitude plays a vital role in contributing to sustainable learning [27]. In the analysis of the intention to use tools based on ICT, it was found that the perceived utility by the students affected their intention to use them [28].

The use of m-learning can contribute to the sustainability of education, but its adoption will depend on a critical analysis of contextual factors, such as those linked to attitudes of students and the quality of websites.

To harness the educational potential of modern technology, it is necessary to create suitable environments and the strategic use of a range of tools that allow autonomous learning, so it is important to evaluate the tools in the design of online environments. Whether perceived utility of online tools causes a positive effect on students, one would expect a positive effect on the m-learning process. 
Accordingly, the objective of this work is to carry out a measurement of perceived utility of online tools by accounting college students. Additionally, student's attitude and perceptions towards several components of the learning environment can be considered as relevant factors for successful online learning. Consequently, in this work, several personal attitudes have also been analyzed.

\section{Literature}

Student's attitude towards the VLE can affect the learning process conditioning different aspects of it. The predisposition to the studied academic subject (understood as the personal attitude towards the contents), especially in accounting, has turned out to be a relevant factor in the learning process. Also, positive attitude towards virtual learning environments and towards the teacher's role in m-learning environments could be relevant factors. These positive attitudes are usually considered as drivers for learning and therefore they can affect the perceived utility of online tools in m-learning. For this reason, various learning drivers are discussed below.

\subsection{Attitudes Towards Accounting and General Skills}

Authors have pointed out that the attitude of student towards accounting can be a determinant factor for learning [29]. Empirical studies analyzed attitudes to find out how students consider accounting as a profession, finding differences due to personal, cultural, and social motivations [30]. Accounting affinity is analyzed through student's attitude, using surveys [31]. Negative attitudes towards accounting is linked to the consideration that accounting is a boring discipline [32], and the unfavorable attitudes cause low performance [33]. Also, some prior work has shown that students have difficulties in understanding accounting rules [34], mainly because the study of accounting involves mathematical and calculation management [35]. The negative attitude towards the study of accounting is usually associated to its abstract nature, and by using visual methods and graphical contents the learning process is improved [36]. Furthermore, the perception of the accounting profession is associated with the family environment and possession of skills such as core mathematical skills [37].

For students taking accounting courses outside of the Business or Economics programs, such as in Tourism Studies, accounting knowledge is equally important to professional performance in the tourism industry, but despite this career objective, these students often perform poorly, which has been linked to a low numerical or analytical ability, which could be improved by positive attitudes involving teachers and students [38]. It is therefore recommendable that the design of accounting courses fosters realistic accounting perceptions, in order to have students with necessary skills [39]. In this way, generic skills are linked to accounting and, as such, can be indirect determinants of the perceived utility of learning tools, and consequently, can be a determining factor for the positive attitude towards accounting (accounting affinity).

\subsection{Attitudes Towards Virtual Learning Environments}

Despite the advantages of online learning tools, students' acceptance is perhaps the most important factor for a successful learning $[1,40]$, hence the need to analyze the satisfaction in virtual learning environments. Virtual environments can be self-developed or can be based on open systems. Even when the VLE is self-developed, it should include only online tools whose benefits have already been corroborated. Nevertheless, to know the students' perceived utility related to online tools, it is necessary to gain a better understanding of how students experience the online learning process. This greater knowledge will allow reconfiguring online tools in order to facilitate a better personal use in the VLE. The effectiveness of online learning environments in accounting has been assessed through student's perception regarding online learning tools within the environment [41], finding a positive relationship between affinity to online learning environments and satisfaction with online learning [42].

Within the affinity for learning in virtual environments, the individual's attitude towards social interaction has been assessed [43]. Social interaction with peers and teachers, are aspects related to the 
problem of loneliness or isolation [44], and they are usually associated to people who do not like virtual environments. Computer and Internet self-confidence has been another issue analyzed in students' attitude towards VLE, finding that this is a discerning factor for the feeling of belonging to a group [45]. In this sense, the empirical analysis has shown that online feedback will be more effective if feedback tools facilitate the perception of social presence [46]. In order to make sure that digital non-natives feel comfortable with the implementation of ICT, the mediating role of a teacher is required to encourage the students in m-learning.

\subsection{Perception of Teacher's Role}

Considering again the aforementioned idea that the method of use and the context of use of technological tools is more important than the tools themselves [1,19], the teacher's role plays a priority objective. Some authors suggest that the absence of an instructor in self-directed learning could lead to errors and problems with skill acquisition [47]. That is the reason that the teacher's role in the online learning processes through mobile technology should be considered as one determining factors of the utility of online learning tools [48]. Teacher's attitude includes the teachers' reactions to several issues and challenges $[49,50]$. The process of the teacher's intervention can provide selected materials, giving advice, motivating interaction with peers, or selecting a well-chosen computer program [51]. This managerial participation in online environments is considered as an orchestration in the classroom [52] and implies the innovative focus in the learning tools design [53]. In this process, two key participants are involved: Teacher and student. Online tools provided and managed by the teacher are considered as important as the student's perception about the utility reported of these tools. In this way, in the present research, the teacher's role in the VLE is considered as a relevant factor for the adequate management of the online tools, and consequently, it considers that this role has an important impact on perceived utility regarding online tools.

The teacher's role in m-learning has been measured through questionnaires aimed at students. The focus of questionnaires depends on the specific research purpose. Most studies combined purposes about the social presence of the teacher in computerized scenarios, teacher's ability to manage the VLE, student's motivation, and the intellectual resolution of questions $[45,54,55]$. There are results that indicate that even students who have positive attitudes require a teacher for various reasons, some linked to the sustainability of m-learning due to the need for motivation [56,57].

\subsection{Perception of Online Tools}

Positive relationships have been found between the valuation of certain visual online tools based on ICTs and performance in the field of accounting [58]. Electronic assessment systems in virtual learning environments were also analyzed from the point of view of the students' perception of their utility, finding a positive attitude due to the rapid feedback they offer and the reduction in rating bias $[59,60]$. The assessment of online tools has been focused on exploring student views on self-directed learning tools [61], e.g., the utility of the virtual classroom and other learning tools $[10,60,62]$. It has been found that tools based on video allow a comprehensive teaching-learning strategy [63], which would enhance the acquisition of various skills.

Resulting from the above arguments, a teaching innovation project was carried out. It was focused on improving the quality and monitoring of students in the online learning environment applied by the university ("Methodological actions to improve the quality and monitoring of students in the e-UNED environment"). The improvement was focused on the utility of online tools and the analysis of explanatory relationships of the utility. This work shows the application of online learning tools for accounting teaching in the European Higher Education Area (EHEA). The purpose is to measure the perceived utility of online tools by students and, also whether personal attitudes of students (affinity) could explain the perceived utility. 


\section{Materials and Methods}

The objectives in this work were reached in accordance with the aforementioned project explained above. Thus, the measurement of perceived utility of online learning tools, the objectives, and the hypotheses were designed and implemented as explained below.

\subsection{Objectives and Hypotheses}

In accordance with the research objectives in the learning environment, which are the measurement of the perceived utility of online tools in an m-learning environment, as well as its explanatory variables, various online tools were applied in the m-learning environment. Implemented online tools for accounting learning consisted of short videos, virtual tutorials, short comics, online questionnaires, online exams, forums and chats, online working groups, and web conferences; which were accessible to all students enrolled in an accounting course within an official program at the EHEA. To measure the perception of the utility of the learning tools, a questionnaire was developed ad hoc. The questionnaire was made up of 5 variables. Each one was supported for a constructor composed of a pool of items. Each item related to an aspect of the variable to be measured.

The variables were: (1) The affinity for accounting (subject under study), (2) the affinity for virtual learning environments, (3) the self-perception of the general skills necessary for accounting, (4) the perception related to the role of the teacher in the virtual learning environment, and (5) the perception of the utility of online tools. Each student was asked to rate each item. To guarantee the validity of the questionnaire, as is common in educational research, the preliminary questionnaire was piloted [64]. The reliability of the questionnaire was ensured by the Cronbach's $\alpha$ (see Table 1), by considering that the minimum value for social sciences must be greater than 0.7 [65].

Table 1. Times, variables, and items.

\begin{tabular}{|c|c|c|c|c|c|}
\hline \multicolumn{2}{|c|}{ T1 } & \multicolumn{2}{|c|}{$\mathrm{T} 2$} & \multicolumn{2}{|c|}{ T3 } \\
\hline \multicolumn{2}{|c|}{$\begin{array}{c}\text { Self-perception of own general } \\
\text { skills (GS_I) }\end{array}$} & \multicolumn{2}{|c|}{$\begin{array}{l}\text { Perception on the teacher's roll } \\
\text { (TCH_I) }\end{array}$} & \multicolumn{2}{|c|}{$\begin{array}{l}\text { Perceived utility of online } \\
\text { learning tools (TOOLS_I) }\end{array}$} \\
\hline \multicolumn{2}{|c|}{ Reliability } & \multicolumn{2}{|c|}{ Reliability } & \multicolumn{2}{|c|}{ Reliability } \\
\hline Cronbach's & & Cronbach's & & Cronbach's & \\
\hline Alpha & $\mathrm{N}$ of Items & Alpha & $\mathrm{N}$ of Items & Alpha & $\mathrm{N}$ of Items \\
\hline 0.795 & 6 & 0.739 & 4 & 0.852 & 9 \\
\hline \multicolumn{6}{|c|}{$\begin{array}{l}\text { Affinity to accounting learning } \\
\text { (ACC_I) }\end{array}$} \\
\hline \multicolumn{2}{|c|}{ Reliability } & & & & \\
\hline $\begin{array}{l}\text { Cronbach's } \\
\text { Alpha }\end{array}$ & $\mathrm{N}$ of Items & & & & \\
\hline 0.873 & 9 & & & & \\
\hline \multicolumn{6}{|c|}{$\begin{array}{l}\text { Affinity to Virtual Learning } \\
\text { Environment (VLE_I) }\end{array}$} \\
\hline \multicolumn{2}{|c|}{ Reliability } & & & & \\
\hline $\begin{array}{l}\text { Cronbach's } \\
\text { Alpha }\end{array}$ & $\mathrm{N}$ of Items & & & & \\
\hline 0.852 & 7 & & & & \\
\hline
\end{tabular}

The questionnaire was carried out in three phases. The first phase was carried out during time 1 (T1), after the start of the course and having already tried the tools for more than three weeks. At that time, variables related to the affinity for accounting (ACC_I), the affinity for learning in virtual environments (VLE_I), and the self-perception of general skills (GS_I) were measured. At time 2 
(T2), at half-term, the perception of the teacher's role was measured. At time 3 (T3), at the final term, the utility attributed to the online tools was measured.

The questionnaire was carried out sequentially in three phases, so that 105 students (T1) initially participated. Seventy-five of those who participated in the first phase also completed the second phase (T2). Finally, 60 of the previous students completed the third phase (T3). Therefore, for the sequential study, the data processing included only the 60 students who participated in all phases.

A summary of the content of each of the items that make up each variable is shown in Table A1 (Appendix A).

According to the measurement and the research objective, the following alternative hypotheses were tested, expecting the following relationships among variables (see Figure 2):

- H1: Self-perception on generic skills by students is a positive explanatory variable of the affinity for accounting learning by linear regression.

- H2: Affinity for virtual learning environments by students is a positive explanatory variable of the affinity for accounting learning by linear regression.

- H3: Affinity for accounting learning by students is a positive explanatory variable of perceived utility of online learning tools by linear regression.

- H4: Perception of teacher's role by students is an explanatory variable of perceived utility of online learning tools by linear regression.

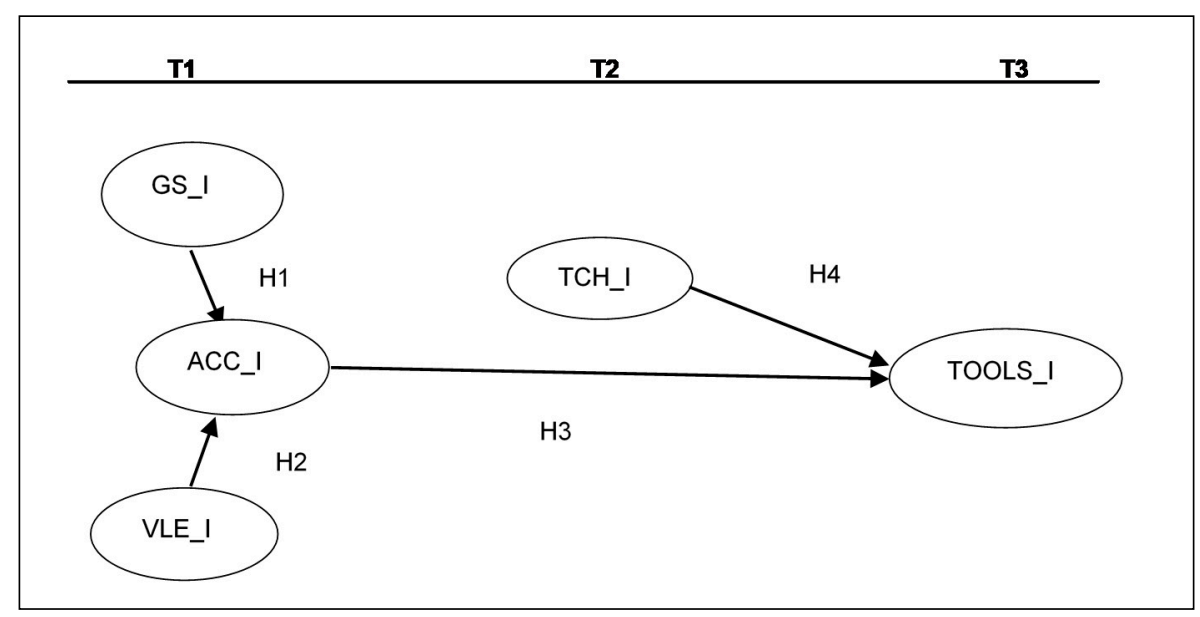

Figure 2. Variables and hypotheses. Notes: The Hypotheses suppose that GS_I and VLE_I have relevant effects on ACC_I at time 1, ACC_I (measured at time 1) and TCH_I (measured at time 2) have relevant effects on TOOLS_I.

\subsection{Sample}

The sample was made up of students who used the online learning tools and completed the questionnaires (T1, T2, and T3). Some of the socio-demographic characteristics of the sample are shown in Table 2. Almost $67 \%$ were women. Fifteen percent were part-time students and $48.3 \%$ of the students were between the age of 26 and 36 years old. It should be noted that only $6.7 \%$ were over 50 years old and only $8.3 \%$ were 25 years old or younger. Sixty percent had no family responsibilities, compared to $40 \%$ who claimed to have family responsibilities (spouse, children, parents, etc., in their care). The questionnaire finished early January 2020. 
Table 2. Times, constructs, and variables.

\begin{tabular}{|c|c|c|c|c|c|}
\hline \multirow{5}{*}{ Valid } & Gender & Frequency & Percent & Valid Percent & Cumulative Percent \\
\hline & Female & 40.0 & 66.7 & 66.7 & 66.7 \\
\hline & Male & 19.0 & 31.7 & 31.7 & 98.3 \\
\hline & Unanswered & 1.0 & 1.7 & 1.7 & 100.0 \\
\hline & Total & 60.0 & 100.0 & 100.0 & \\
\hline \multirow{6}{*}{ Valid } & Part Time & & & & \\
\hline & Students & Freouency & Percent & Valid Percent & Cumulative Percent \\
\hline & $\begin{array}{l}\text { (Students } \\
\text { Working) }\end{array}$ & शтечиепу & & & \\
\hline & Workers & 9.0 & 15.0 & 15.0 & 15.0 \\
\hline & Non-workers & 51.0 & 85.0 & 85.0 & 100.0 \\
\hline & Total & 60.0 & 100.0 & 100.0 & \\
\hline \multirow{6}{*}{ Valid } & Age & Frequency & Percent & Valid Percent & Cumulative Percent \\
\hline & 18-25 years old & 5.0 & 8.3 & 8.3 & 8.3 \\
\hline & $26-36$ years old & 29.0 & 48.3 & 48.3 & 56.7 \\
\hline & $37-50$ years old & 22.0 & 36.7 & 36.7 & 93.3 \\
\hline & Mas de 50 years old & 4.0 & 6.7 & 6.7 & 100.0 \\
\hline & Total & 60.0 & 100.0 & 100.0 & \\
\hline \multirow{4}{*}{ Valid } & $\begin{array}{c}\text { Family } \\
\text { Responsibilities }\end{array}$ & Frequency & Percent & Valid Percent & Cumulative Percent \\
\hline & $\mathrm{No}$ & 36.0 & 60.0 & 60.0 & 60.0 \\
\hline & Yes & 24.0 & 40.0 & 40.0 & 100.0 \\
\hline & Total & 60.0 & 100.0 & 100.0 & \\
\hline
\end{tabular}

Source: Own development.

\subsection{Variables and Measures}

Students' positioning was summarized using scoring indicators. Score analysis is a popular statistical method of processing data for causal inference [66,67]. They are usually applied to summarize, in a single number, the students' attitude towards specific issue [68]. In accounting, scoring indicators have been used to measure students' attitudes towards the perceptions about Accounting $[29,69,70]$ and accounting teachers' attitudes [71]. Furthermore, in the field of accounting, scoring indicators have been applied to measure attitudes towards virtual learning environments [72].

This research assumed that a higher indicator of student's attitudes towards Accounting should lead to a higher perception about utility of online tools. In this way, the explanatory variables, which were designed as scoring indicators, offer a score of the student positioning regarding the drivers of perceived utility. Each variable was elaborated by quotient between the sum of the scores of all the items (see Table 2) and the maximum score that variable could take. Thus, the following variables, were made:

- Self-perception of own generic skills: $\left.G S_{I}=\left[\sum_{i=1}^{6} G S i\right) / 30\right]$;

- Affinity to accounting learning: $\left.A C C_{-} I=\left[\sum_{i=1}^{9} A C C i\right) / 45\right]$;

- Affinity to Virtual Learning Environment: $\left.V L E_{-} I=\left[\sum_{i=1}^{7} V L E i\right) / 35\right]$;

- Perception on the Teacher's role: _TCH_I $\left.=\left[\sum_{i=1}^{4} T C H i\right) / 20\right]$.

Furthermore, the explained variable, which is the indicator of perceived utility related to online tools, was similarly made and continues with the following mathematical expression: TOOLS_I $=\left[\sum_{i=1}^{9}\right.$ TOOLSi) $\left./ 45\right]$.

The variables were made by using similar items from prior works:

- The attitude towards Accounting was composed of 9 items, which were self-constructed from prior works $[29,31,37,39,57]$. 
- The attitude towards VLE was composed of 7 items self-constructed from prior studies on functionality and interaction [41-45].

- The self-perception on general skills of students was composed of 6 items. These items were taken from the specifications in the Official Educational Report of the University Degree in Tourism, regarding generic skills for accounting matter. These generic skills are like those defined in other official programs in Spain and European Union, according to desirable skills for accountant professionals. These items have been involved in prior works [42,57].

- The positive perception on the teacher's role was composed of 4 items, according to prior works [42,45,57].

- The perceived utility of online tools was composed of 9 items, and these were distributed as follows: 1 item related to the short introductory course to basic accounting, 2 related to forums, 2 related to self-evaluations, 3 related to videos of accounting contents, and 1 related to accounting short comics. All the items ask about the contribution of the specific tool in different aspects of learning, considering prior literature [42,59,61-63].

\subsection{Statistical Hypotheses Fit}

Linear regressions have been applied to measure the predictive capacity of online tools in blended learning environments [73]. More specifically, multi-regression analysis has also been applied to analyses attitudes towards ICT in online courses, finding that the effectiveness of online courses can be explained by student's attitude towards ICT factors [74]. Also, statistical correlations by SPSS have been applied for analysis of perceptions [75]. In the same way, linear regression has been a good statistical tool to identify predictor variables based on students' perceptions related to students' experience in their use of online tools, such as videos [10]. In the field of attitude analysis towards learning contents with a higher numerical component, regression analysis has been shown as a useful tool [76], and regression has also been applied to measure the effect of accounting undergraduates' attitudes related to ethical commitment [77]. In educational studies, regression analysis is used to explore the relationship between students' behaviors and achievements in online settings [78].

According to prior literature, the statistics analysis of this work was based on linear regression to determine whether variables at T1 and T2 could be explanatory variables of the tools' utility, which is the explained variable (dependent variable) at the end of the period (T3). Likewise, the explanatory relationships among variables at T1 were also analyzed by linear regression. Previously, in order to select the involved variables in the linear regression models, a correlation analysis was carried out to detect what variables had shown statistical association.

Correlation analysis was used to establish the statistical association between the variables. Since the correlation analysis only implies the association between two variables, but not the statistical causality of one over the other, linear regressions were applied to establish the causality.

Therefore, for each linear regression, the dependent variable and the independent variables (explanatory variables) are shown. In addition, for each regression, the fit of the model calculated by $\mathrm{R}^{2}$ is shown, which is used to see the degree of intensity or effectiveness that the independent variables have in order to explain the dependent variable.

Furthermore, for each regression, ANOVA is used to show the statistic and its level of significance (sig.). If the significance is less than or equal to 0.05 , the null hypothesis is rejected and the alternative hypothesis is accepted, which is the one proposed in social sciences as an objective to be demonstrated. Likewise, for each regression, the non-standardized coefficients and their level of significance are determined. When the significance level is less than or equal to 0.05 , it is statistically considered that the variable or constant for that significance provides an explanation for the model. In this way, those coefficients with a significance level greater than 0.05 do not contribute at all to the explanation of the dependent variable and, consequently, this can be eliminated from the model.

The present work analyzed what variables are associated and whether the relationship between them was explanatory, taking the phases of the study into account. Thus, different regressions were 
related until concluding the third phase of the study with the best explanatory regression of the perceived utility of online tools. In this way, the initial hypothetical model that is based on the specialized literature takes the form of a set of statistically causal relationships that explains the variable, which is the objective of the analysis. That is, the perceived utility of the online tools and determinant attitudinal variables.

\section{Results}

The statistical results have been organized in three sections, one for descriptive statistics, another for relationships between the variables in $\mathrm{T} 1$, and the last one for the relationships of all variables with the target variable (utility of online tools).

\subsection{Descriptive Statistics}

The affinity towards accounting (ACC_I) and the affinity towards virtual learning environments (VLE_I) are positioned in the first quartile, while the rest of the indicators are positioned in the second quartile, taking the ACC_I as the highest value (see Table 3). Values of all variables indicated that most of the college students in the m-learning environment had a good predisposition towards accounting. Undergraduates considered that they themselves have high generic skills useful for studying accounting (T1). Variables at T2 and T3 show that university students had a high perception of the teacher's role and the utility of online tools. The perception of students related to the utility of online tools assumed high values. These results led to an analysis of the explanatory relationship among variables at $\mathrm{T} 1, \mathrm{~T} 2$, and $\mathrm{T} 3$, and thus, to correlations and linear regression analysis.

Table 3. Descriptive statistics.

\begin{tabular}{ccccccc}
\hline Variables & N & Minimum & Maximum & Mean & Quartile & Std. Deviation \\
\hline ACC_I & 60 & 0.36 & 1.00 & 0.7622 & Q1 & 0.14467 \\
VLE_I & 60 & 0.20 & 1.00 & 0.7543 & Q1 & 0.17080 \\
\hline GS_I & 60 & 0.20 & 0.97 & 0.7322 & Q2 & 0.13290 \\
TOOLS_I & 60 & 0.29 & 1.00 & 0.6737 & Q2 & 0.16389 \\
TCH_I & 60 & 0.20 & 1.00 & 0.6608 & Q2 & 0.17758 \\
\hline
\end{tabular}

Source: Own development from SPSS.

\subsection{Correlations and Regressions at Time 1}

The analysis of bivariate correlation applied on variables at T1 points to a possible explanatory relationship by peers between variables (see Table 4). In order to show whether there are some explanatory relationships by peers, bivariate linear regressions were done but only considering the perception of accounting as the dependent variable according to prior literature on the effect of student's attitude towards accounting in the online learning.

Table 4. Bivariate correlations at T1.

\begin{tabular}{ccccc}
\hline \multicolumn{2}{c}{ Correlations with Sig-Levels } & GS_I & VLE_I & ACC_I \\
\hline \multirow{2}{*}{ GS_I } & Pearson Correlation & 1.000 & $0.410^{* *}$ & $0.361^{* *}$ \\
& Sig. (2-tailed) & & 0.001 & 0.005 \\
\hline \multirow{2}{*}{ VLE_I } & Pearson Correlation & $0.410^{* *}$ & 1.000 & $0.326^{*}$ \\
& Sig. (2-tailed) & 0.001 & & 0.011 \\
\hline \multirow{2}{*}{ ACC_I } & Pearson Correlation & $0.361^{* *}$ & $0.326^{*}$ & 1.000 \\
& Sig. (2-tailed) & 0.005 & 0.011 & \\
\hline
\end{tabular}

Source: Own development from SPSS. 
Table 4 corroborates the association between the variables at time 1, leading these results to the linear regression analysis. The $\mathrm{R}^{2}$ for each simple linear regression shows that generic skills (GS_I) and the affinity to virtual learning environments (VLE_I) can explain $13 \%$ and $10 \%$ of the perception on Accounting (ACC_I) by students, respectively (see Tables 5 and 6).

Table 5. Linear regression ACC_I/GS_I.

\begin{tabular}{|c|c|c|c|c|c|c|}
\hline \multicolumn{7}{|c|}{ ACC_I (Dependent variable)/GS_I (Ind. variable) } \\
\hline Model & $\mathrm{R}$ & $\mathrm{R}^{2}$ & Adjusted $\mathrm{R}^{2}$ & \multicolumn{3}{|c|}{ Std. Error } \\
\hline 1 & 0.361 & 0.130 & 0.115 & \multicolumn{3}{|c|}{0.13608} \\
\hline \multicolumn{7}{|c|}{ ANOVA } \\
\hline & Model & Sum of Squares & df & Mean Square & $\mathrm{F}$ & Sig. \\
\hline \multirow{3}{*}{1} & Regression & 00.161 & 1 & 0.161 & \multirow[t]{3}{*}{8.682} & \multirow[t]{3}{*}{$0.005^{b}$} \\
\hline & Residual & 1.074 & 58 & 0.019 & & \\
\hline & Total & 1.235 & 59 & & & \\
\hline \multicolumn{7}{|c|}{ Coefficients } \\
\hline \multirow{2}{*}{\multicolumn{2}{|c|}{ Model }} & Unstandardizec & oefficients & \multirow{2}{*}{$\begin{array}{c}\text { Standardized } \\
\text { Coefficients } \\
\text { Beta }\end{array}$} & \multirow{2}{*}{$\mathrm{t}$} & \multirow{2}{*}{ Sig. } \\
\hline & & B & Std. Error & & & \\
\hline \multirow{2}{*}{1} & (Constant) & 0.475 & 0.099 & & 4.786 & 0.000 \\
\hline & GS_I & 0.393 & 0.133 & 0.361 & 2.947 & 0.005 \\
\hline \multicolumn{7}{|c|}{ Dependent Variable: ACC_I, Predictors: (Constant), GS_I } \\
\hline
\end{tabular}

Table 6. Simple linear regression ACC_I/VLE_I.

\begin{tabular}{|c|c|c|c|c|c|c|}
\hline \multicolumn{7}{|c|}{ ACC_I (Dependent variable)/VLE_I (Ind. variable) } \\
\hline \multirow[t]{2}{*}{ Model } & $\mathrm{R}$ & \multirow{2}{*}{$\begin{array}{c}R^{2} \\
0.326\end{array}$} & \multirow{2}{*}{$\begin{array}{c}\text { Adjusted } \mathrm{R}^{2} \\
0.106\end{array}$} & \multicolumn{3}{|c|}{ Std. Error } \\
\hline & 2 & & & 0.091 & & 96 \\
\hline \multicolumn{7}{|c|}{ ANOVA } \\
\hline & Model & Sum of Squares & df & Mean Square & $\mathrm{F}$ & Sig. \\
\hline \multirow{3}{*}{2} & Regression & 0.131 & 1 & 0.131 & 6.882 & $0.011^{\mathrm{b}}$ \\
\hline & Residual & 1.104 & 58 & 0.019 & & \\
\hline & Total & 1.235 & 59 & & & \\
\hline \multicolumn{7}{|c|}{ Coefficients } \\
\hline \multirow{2}{*}{\multicolumn{2}{|c|}{ Model }} & \multicolumn{2}{|c|}{ Unstandardized Coefficients } & $\begin{array}{c}\text { Standardized } \\
\text { Coefficients }\end{array}$ & $t$ & Sig. \\
\hline & & B & Std. Error & Beta & & \\
\hline \multirow{2}{*}{2} & (Constant) & 0.554 & 0.081 & & 6.817 & 0.000 \\
\hline & VLE_I & 0.276 & 0.105 & 0.326 & 2.623 & 0.011 \\
\hline \multicolumn{7}{|c|}{ Dependent Variable: I_ACC, Predictors: (Constant), I_VLE } \\
\hline
\end{tabular}

VLE_I explains more than $10 \%$ of the variation of ACC_I (See Table 6).

Generic skills of students (GS_I) can also explain 13\% of accounting affinity (ACC_I) by a linear regression. The variable and constant are explanatory factors of the accounting affinity, both two (sig. $<0.05$ for each one) (See Table 3). Also, the relationship between personal accounting affinity and personal affinity towards the learning environment based on mobile devices (VLE) shows that the personal affinity to online learning can explain $10.6 \%$ of the dependent variable by simple linear 
regression (See Table 5), and so accounting affinity depends on the personal attitude towards VLE based on mobile devices and the self-perception of personal general skills (see Table 7).

Table 7. Multiple linear regression (Dependent variable: ACC_I/Explanatory variables: VLE_I, GS_I).

\begin{tabular}{|c|c|c|c|c|c|c|}
\hline \multicolumn{7}{|c|}{ ACC_I (Dependent variable)/GS_I. VLE_I (Ind. variables) } \\
\hline \multirow[t]{2}{*}{ Model } & \multicolumn{2}{|r|}{$\mathrm{R}$} & \multirow{2}{*}{$\frac{\mathrm{R}^{2}}{0.168}$} & \multirow{2}{*}{$\begin{array}{c}\text { Adjusted } \mathrm{R}^{2} \\
0.139\end{array}$} & \multicolumn{2}{|c|}{ Std. Error } \\
\hline & 3 & \multirow[t]{2}{*}{0.410} & & & \multicolumn{2}{|c|}{0.13424} \\
\hline \multicolumn{6}{|c|}{ ANOVA } & \\
\hline & Model & Sum of Squares & $\mathrm{df}$ & Mean Square & $\mathrm{F}$ & Sig. \\
\hline \multirow{3}{*}{3} & Regression & 0.208 & 2 & 0.104 & \multirow[t]{3}{*}{5.761} & \multirow[t]{3}{*}{$0.005^{b}$} \\
\hline & Residual & 1.027 & 57 & 0.018 & & \\
\hline & Total & 1.235 & 59 & & & \\
\hline \multicolumn{7}{|c|}{ Coefficients } \\
\hline \multirow{2}{*}{\multicolumn{2}{|c|}{ Model }} & \multicolumn{2}{|c|}{ Unstandardized Coefficients } & $\begin{array}{l}\text { Standardized } \\
\text { Coefficients }\end{array}$ & \multirow{2}{*}{$\mathrm{t}$} & \multirow{2}{*}{ Sig. } \\
\hline & & B & Std. Error & Beta & & \\
\hline \multirow{3}{*}{3} & (Constant) & 0.408 & 0.106 & & 3.841 & 0.000 \\
\hline & GS_I & 0.297 & 0.144 & 0.273 & 2.063 & 0.044 \\
\hline & VLE_I & 0.181 & 0.112 & 0.214 & 1.613 & 0.112 \\
\hline & Depe & nt Variable: $\mathrm{ACC}$ & edictors: (C & istant), VLE_I, & & \\
\hline
\end{tabular}

Regarding the results of multiple regression (see Table 7), the joint effect of VLE_I and GS_I explain $16.8 \%$ of the variance of ACC_I, but, according to the significance of each variable, VLE_I is a non-significant variable in the multiple regression (Sig $=0.112>0.05$ ). In order to explain ACC_I, the final regression would be ACC_I $=0.408+0.297$ GS_I for variables at time 1 . Nevertheless, in order to study the role between GS_I and VLE_I, a linear regression analysis was carried out (See Table 8).

Table 8. Linear regression GS_I/VLE_I.

\begin{tabular}{|c|c|c|c|c|c|c|}
\hline \multicolumn{7}{|c|}{ Model Summary-GS_I } \\
\hline Model & $\mathrm{R}$ & \multicolumn{2}{|l|}{$\mathrm{R}^{2}$} & Adjusted $\mathrm{R}^{2}$ & \multicolumn{2}{|c|}{ Std. Error } \\
\hline 4 & 0.410 & \multicolumn{2}{|c|}{0.168} & 0.154 & \multicolumn{2}{|c|}{0.12225} \\
\hline \multicolumn{7}{|c|}{ ANOVA } \\
\hline & Model & Sum of Squares & $\mathrm{df}$ & Mean Square & $\mathrm{F}$ & Sig. \\
\hline \multirow{3}{*}{4} & Regression & 0.175 & 1 & 0.175 & \multirow[t]{3}{*}{11.732} & \multirow[t]{3}{*}{$0.001^{\mathrm{b}}$} \\
\hline & Residual & 0.867 & 58 & 0.015 & & \\
\hline & Total & 1.042 & 59 & & & \\
\hline \multicolumn{7}{|c|}{ Coefficients } \\
\hline \multirow{2}{*}{\multicolumn{2}{|c|}{ Model }} & \multicolumn{2}{|c|}{ Unstandardized Coefficients } & Standardized & \multirow{2}{*}{$\mathrm{t}$} & \multirow{2}{*}{ Sig. } \\
\hline & & B & Std. Error & Beta & & \\
\hline \multirow{2}{*}{4} & (Constant) & 0.491 & 0.072 & \multirow[b]{2}{*}{0.410} & 6.823 & 0.000 \\
\hline & I_VLE & 0.319 & 0.093 & & 3.425 & 0.001 \\
\hline \multicolumn{7}{|c|}{ Dependent Variable: GS_I, Predictors: (Constant), VLE_I } \\
\hline
\end{tabular}


VLE_I can explain more than $16 \%$ of the behavior of GS_I. This implies that undergraduates with a greater affinity for virtual learning environments often perceive their general skills as high. In this way, the regression would respond to the following equation: GS_I $=0.491+0.319$ VLE_I.

\subsection{Regressions for Utility Perceived of Online Tools}

The coefficient of correlation between all one-to-one variables was considered in order to fit linear regressions (See Table 9).

Table 9. Coefficients of correlations for all variables.

\begin{tabular}{ccccccc}
\hline & Correlations & GS_I & VLE_I & ACC_I & TCH_I & TOOLS_I \\
\hline GS_I & Pearson Correlation & 1.000 & $0.410^{* *}$ & $0.361^{* *}$ & 0.108 & $0.314^{*}$ \\
\hline VLE_I & Pearson Correlation & $0.410^{* *}$ & 1.000 & $0.326^{*}$ & 0.080 & $0.346^{* *}$ \\
\hline ACC_I & Pearson Correlation & $0.361^{* *}$ & $0.326^{*}$ & 1.000 & 0.155 & $0.412^{* *}$ \\
\hline TCH_I & Pearson Correlation & 0.108 & 0.080 & 0.155 & 1.000 & $0.469^{* *}$ \\
\hline TOOLS_I & Pearson Correlation & $0.314^{*}$ & $0.346^{* *}$ & $0.412^{* *}$ & $0.469^{* *}$ & 1.000 \\
\hline
\end{tabular}

Source: Own development from SPSS.

The results do not show correlation among TCH_I (T2) and the variables at Time 1. However, TCH_I (T2) correlates positively with TOOLS_I (T3), that is the final objective. Variables measured at T1 (GS_I, VLE_I, and ACC_I) correlate with TOOLS_I (T3). Consequently, several regressions were performed to test whether relationships among TOOLS_I and its correlated variables correspond to spurious or causal correlations.

According to the specific literature, the behavior of the teacher plays an important relevance in student learning. Furthermore, the affinity to Accounting plays a relevant role for learning. By focusing the analysis of the learning process on the perceived utility by college students, the utility of online tools was analyzed as a dependent variable, which should be explained by accounting affinity and the teacher's role. In this way, multiple linear regression was used to fit the behavior of TOOLS_I but only considering the significant variables at T1 and T2. The results show that the joint effect of all variables could explain $39 \%$ of the variability of TOOLS_I $\left(R^{2}=39 \%\right)$, but the significance of standardized coefficients note that only ACC_I and TCH_I add value to the model (sig.: 0.036 and 0.000 , respectively), so that the other variables (GS_I and VLE_I) and the constant can be eliminated for the significance (sig. > 0.05) (see Table 10).

The results of the multiple linear regression considering all variables at $\mathrm{T} 1$ and $\mathrm{T} 2$, show that joint effect of all variables explain $39 \%\left(\mathrm{R}^{2}\right)$ of the perceived utility of online tools (TOOLS_I). The significance of standardized coefficients (Beta) specify that only the accounting affinity (ACC_I) and the perceived role of teacher in mobile environments designed as virtual classrooms (TCH_I) were significant variables to the perceived utility of online tools (TOOLS_I) (See Table 10). For this reason, the regression for explaining the behavior of TOOLS_I must be performed only with the relevant variables, which are TCH_I and ACC_I.

Considering only these two variables (TCH_I and ACC_I), the results of linear regression specify that the joint effect of ACC_I and TCH_I can explain 33.8\% of the behavior of TOOLS_I (see Table 11). The coefficients show that the constant can be eliminated of the model because the critical level associated with the statistic (sig.) is greater than 0.05 ( $\mathrm{sig}=0.269>0.05)$. The final regression to explain the utility of tools in learning focus on mobile devices responds to the following equation: TOOLS_I $=0.394$ ACC_I +0.383 TCH_I. 
Table 10. Multiple linear regression (Dependent variable: TOOLS_I/Explanatory variables: TCH_I, VLE_I, ACC_I, GS_I).

\begin{tabular}{|c|c|c|c|c|c|c|}
\hline \multicolumn{7}{|c|}{ Model Summary } \\
\hline Model & $\mathrm{R}$ & \multicolumn{2}{|c|}{$\mathrm{R}^{2}$} & Adjusted $\mathrm{R}^{2}$ & \multicolumn{2}{|c|}{ Std. Error } \\
\hline 5 & 0.625 & \multicolumn{2}{|c|}{0.390} & 0.346 & \multicolumn{2}{|c|}{0.13252} \\
\hline \multicolumn{7}{|c|}{ ANOVA } \\
\hline & Model & Sum of Squares & $\mathrm{df}$ & Mean Square & $\mathrm{F}$ & Sig. \\
\hline \multirow{3}{*}{5} & Regression & 0.619 & 4 & 0.155 & \multirow[t]{3}{*}{8.809} & \multirow[t]{3}{*}{$0.000^{b}$} \\
\hline & Residual & 0.966 & 55 & 0.018 & & \\
\hline & Total & 1.585 & 59 & & & \\
\hline \multicolumn{7}{|c|}{ Coefficients } \\
\hline \multirow{2}{*}{\multicolumn{2}{|c|}{ Model }} & \multicolumn{2}{|c|}{ Unstandardized Coefficients } & $\begin{array}{l}\text { Standardized } \\
\text { Coefficients }\end{array}$ & \multirow{2}{*}{$\mathrm{T}$} & \multirow{2}{*}{ Sig. } \\
\hline & & B & Std. Error & Beta & & \\
\hline \multirow{5}{*}{5} & (Constant) & -0.019 & 0.127 & & -0.147 & 0.884 \\
\hline & GS_I & 0.125 & 0.148 & 0.102 & 0.849 & 0.399 \\
\hline & VLE_I & 0.183 & 0.113 & 0.190 & 1.612 & 0.113 \\
\hline & ACC_I & 0.284 & 0.132 & 0.251 & 2.156 & 0.036 \\
\hline & TCH_I & 0.373 & 0.099 & 0.404 & 3.783 & 0.000 \\
\hline \multicolumn{7}{|c|}{ Predictors: (Constant), TCH_I, VLE_I, ACC_I, GS_I; Dependent Variable: TOOLS_I } \\
\hline
\end{tabular}

Source: Own development from SPSS.

Table 11. Multiple linear regression (Dependent variable: TOOLS_I/Explanatory variables: TCH_I, ACC_I).

\begin{tabular}{|c|c|c|c|c|c|c|}
\hline \multicolumn{7}{|c|}{ Model Summary ${ }^{b}$} \\
\hline Model & $\mathrm{R}$ & \multicolumn{2}{|l|}{$\mathrm{R}^{2}$} & Adjusted $\mathrm{R}^{2}$ & \multicolumn{2}{|c|}{$\begin{array}{l}\text { Std. Error of the } \\
\text { Estimate }\end{array}$} \\
\hline 6 & 0.581 & \multicolumn{2}{|c|}{0.338} & 0.315 & \multicolumn{2}{|c|}{0.13567} \\
\hline \multicolumn{7}{|c|}{ ANOVA } \\
\hline & Model & Sum of Squares & $\mathrm{df}$ & Mean Square & $\mathrm{F}$ & Sig. \\
\hline \multirow{3}{*}{6} & Regression & 0.535 & 2 & 0.268 & \multirow[t]{3}{*}{14.545} & \multirow[t]{3}{*}{$0.000^{\mathrm{b}}$} \\
\hline & Residual & 1.049 & 57 & 0.018 & & \\
\hline & Total & 1.585 & 59 & & & \\
\hline \multicolumn{7}{|c|}{ Coefficients } \\
\hline \multirow{2}{*}{\multicolumn{2}{|c|}{ Model }} & \multicolumn{2}{|c|}{ Unstandardized Coefficients } & $\begin{array}{l}\text { Standardized } \\
\text { Coefficients }\end{array}$ & \multirow{2}{*}{$\mathrm{t}$} & \multirow{2}{*}{ Sig. } \\
\hline & & B & Std. Error & Beta & & \\
\hline \multirow{3}{*}{6} & (Constant) & 0.120 & 0.108 & & 1.116 & 0.269 \\
\hline & ACC_I & 0.394 & 0.124 & 0.348 & 3.185 & 0.002 \\
\hline & TCH_I & 0.383 & 0.101 & 0.415 & 3.804 & 0.000 \\
\hline \multicolumn{7}{|c|}{ Predictors: (Constant), TCH_I, ACC_I; Dependent Variable: TOOLS_I } \\
\hline
\end{tabular}

Considering all the statistical analysis carried out in this work, the resulting linear relationships among the variables analyzed are shown in Figure 3. 


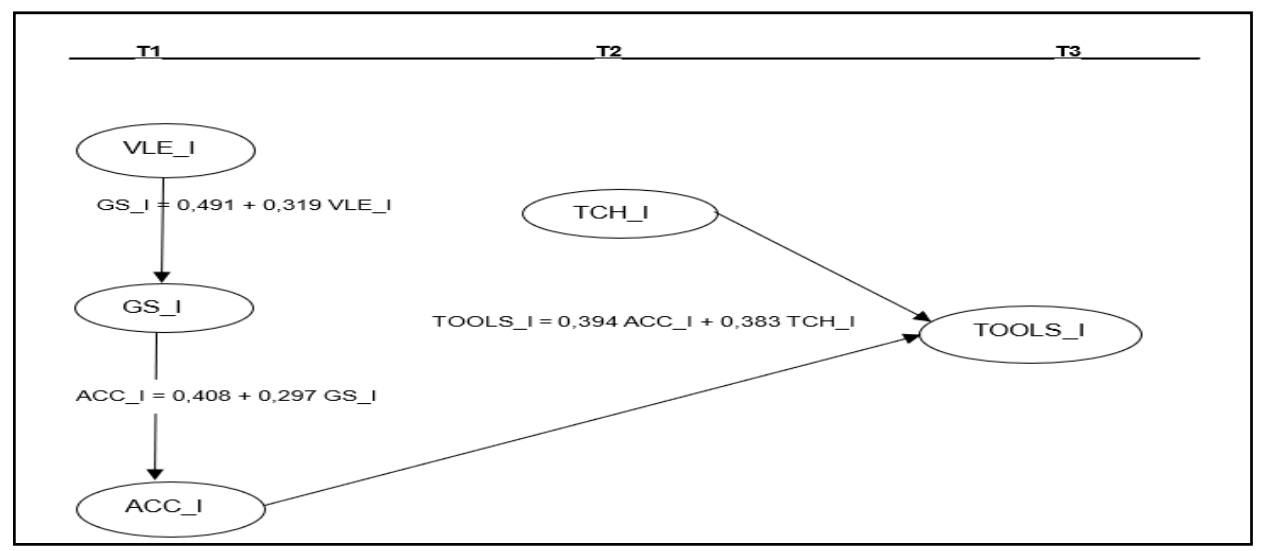

Figure 3. Findings on explanatory variables and linear regressions. Notes: After considering the results, VLE_I is a relevant variable on GS_I, GS_I is a relevant variable on ACC_I, ACC_I and TCH_I are relevant variables on TOOLS_I.

Thus, considering the joint results, $\mathrm{H} 1$ is accepted. It implies that the self-perception of generic skills (GS_I) is an explanatory variable of the affinity for accounting learning (ACC_I). Nevertheless, $\mathrm{H} 2$ is rejected and so the affinity to virtual learning environment (VLE_I) is not directly an explanatory variable of the affinity for accounting learning (ACC_I) at T1. H3 and H4 are both accepted. It implies that the accounting affinity (ACC_I) and the teacher's role are explanatory variables of the perceived utility of online learning tools, both jointly. The joint effect of these explanatory variables can explain $33.8 \%$ of the variability of the undergraduates' perception of online learning tools.

\subsection{Summary of Results}

In order to measure the perceived utility of m-learning tools and the relationships with explanatory variables, and consequently the validity of the hypotheses, the following relationships were analyzed.

\subsubsection{Regressions Carried out Sequentially at $\mathrm{T} 1$}

(1) Linear regression ACC_I/GS_I: The variable related to generic skills (GS_I) explains $11.5 \%$ (Adjusted $\mathrm{R}^{2}$ ) of the Accounting Attitude (ACC_I) (see Table 5), that implies the acceptance of $\mathrm{H}_{1}$.

(2) Linear regression ACC_I/VLE_I: The variable related to positive attitude towards e-learning (VLE_I) explains 10.5\% (Adjusted R ${ }^{2}$ ) of Accounting Attitude (ACC_I) (See Table 6).

(3) Multiple linear regression by considering ACC_I as dependent variable, and VLE_I and GS_I as explanatory variables: The joint effect of VLE_I and GS_I can explain 13.9\% (Adjusted $\mathrm{R}^{2}$ ) of Accounting Attitude, but VLE_I does not contribute to the model (sig for Beta VLE_I $=0.112>$ $p$-value of 0.05) (See Table 7). This result drives to test whether there is a latent relationship between VLE_I and GS_I, as it can see in the following regression.

(4) Linear regression GS_I/VLE_I: VLE_I explains $16.8 \%$ (Adjusted $\mathrm{R}^{2}$ ) of GS_I (see Table 8). Considering the results of the previous regression $(2,3$, and 4$), \mathrm{H}_{2}$ is rejected because VLE_I does not directly explain ACC_I, but VLE_I explains GS_I (see Figure 3).

4.4.2. Regressions to Measure the Effect of Variables at T1 and T2 over Perceived Utility of Online Tools (T3)

Considering the result of the correlation (see Table 9), a multiple linear regression was carried out, by considering the perceived utility of online tools (TOOLS_I) as dependent variable, and the other variables as independent variables. Independent variables can explain 39\% of the TOOLS_I, but only ACC_I and TCH_I are relevant variables to explain the behavior of TOOLS_I (sig. for Beta ACC_I $=0.036<p$-value of 0.05; and sig for Beta TCH_I $=0.000<p$-value of 0.05) (See Table 10). The $p$-value of significance implies that the only variables that provide an explanation to the perceived 
utility are the teacher's perception and the attitude towards accounting. Consequently, the final multiple regression is performed (see Table 11). Thus, TOOLS_I is the dependent variable (explained variable), and TCH_I and ACC_I are the explanatory variables.

According to the previous arguments, it can finally be concluded that the perceived utility of online tools is explained by perceived teacher's role and accounting attitude, through the following regression: TOOLS_I $=0.394$ ACC_I +0.383 TCH_I, that supposes the acceptance of $\mathrm{H}_{3}$ and $\mathrm{H}_{4}$.

Furthermore, Accounting attitude is explained by student's generic skills, and this variable (GS_I) is explained by Attitude towards virtual learning environment (VLE_I). These regressions and the relationships among variables are shown in Figure 3, which summaries the final explanatory model of perceived utility of online tools that applied in the m-learning evaluated environment. The joint effect of the accounting attitude and the perceived teacher's role can explain the $33.8\left(R^{2}\right)$ of the perceived utility of online tools (See Table 11).

\section{Discussion, Limitations, and Conclusions}

Learning in the mobile age is thinking about virtual learning environments without any physical classroom, without schedules, and without limitations on age, geographic location, or financial resources. The so-called m-learning is seen as the potential scenario for the sustainable development of continuing education throughout life. Considering the heutagogy approach, the continuing education of mature students throughout life is a challenge and, at the same time, a need established as a social objective by countries and international organizations [21]. It is in this teaching field where m-learning can perhaps offer more possibilities in order to implement the sustainability of continuous learning [22]. No one doubts the facts that the characteristics of mobile devices $[1,7,8]$ represent a set of advantages to facilitate this continuous and sustainable learning, due to the educational opportunities of IT $[5,6]$. One of the drawbacks, especially at an early age, is the technological dependence that it can generate in the student, to the detriment of the physical and mental development. It is for this reason that the mere sum of teaching tools accessible from mobile devices, which are hosted on a website, do not represent a profitable m-learning environment for the sustainability of continuous learning throughout life [1,19].

Due to effect that the attitude of students may have on the sustainability process of m-learning [23,27], some studies concluded the need to analyze the perceptions of students about online tools [28] and the teacher's role [25]. In the present study, the analysis regarding the student's perspective has been focused on the analysis of the utility perceived by students regarding online tools, as well as the effect that certain attitudes or the teacher's role may have on the perceived utility of the tools.

Consequently, two main objectives were set for this investigation. The first was to measure the utility perceived by students in relation to online tools in the m-learning environment. The second was to establish the effect of students' attitudinal variables on their perception about utility of online learning tools. Thereby, four hypotheses were raised regarding the effect of attitudinal variables on perceived utility.

In relation to the first objective of the research, related to the perceived usefulness of online tools, the descriptive data allow us to conclude that mature students involved in a Tourism program in the EHEA consider learning tools highly useful ( 0.67 of a maximum 1.00 , see Table 3$)$. Within the attitude variables, they think they have a very high affinity for accounting (0.7622) and for learning in the virtual environment itself (0.7543). According to the results of the previous studies, the positive attitude towards accounting is associated with the understanding of numerical and logical processes $[34,35,37]$. The results of our study are in accordance with this affirmation, since the students also attributed a high score to their generic abilities (0.7322). They also show good predispositions for learning in virtual environments (0.7543), despite being mature students with family responsibilities. Both affinities (accounting learning and VLE), are positioned in the first quartile. Considering only the two scoring indicators in the first quartile (ACC_I and VLE_I), it could be assumed that both variables play an important explanatory capacity of the utility of online tools. 
Regarding previous scoring indicators, the first conclusion of this work is the suitability of the variables developed to measure the affinity for accounting, the affinity for online learning, the self-perception of generic skills, the role of the teacher, and the utility of learning tools in m-learning (see Table 1).

Taking the suitability of the measures developed for the variables (score indicators) into account and according to previous works $[29,69,70]$, the perceived usefulness of the learning tools in this line could be explained by the student's attitude towards accounting and the teacher's role.

In this way, attending to the second objective, related to the explanatory relationships between the attitudinal variables (ACC_I, GS_I, and VLE_I), the teacher's role perception and the perceived utility of online tools (TOOLS_I), our results corroborate a positive and explanatory linear association between the role of the teacher and the perceived utility of online tools, as well as a similar explanatory relationship between affinity for accounting and the perceived utility of tools. The joint effect of both variables can explain $33.8 \%$ of the utility (see Figure 3 and Table 11) and so therefore, the acceptance of hypothesis 4 .

Consequently, the main conclusion is that the teacher's role as an instructor for autonomous online learning in a process of sustainable distance education must be considered to plan the tools for the m-learning. Likewise, the affinity towards the learning contents might also be considered in order to design environments based on m-learning, due to the fact that the student's attitude towards contents is related to the perceived utility.

Other secondary results confirm that the students give a high score to the teacher's ability to solve problems [49], the teacher's role as motivator of m-learning process [45,56,57], and the teacher's role as online tools manager [51-53,57]. Likewise, the results confirm the importance of the teacher's role for the transactional presence, which occurs when the student perceives that there is someone on the other side of the mobile device during the learning process [54,55]. These secondary findings would imply the innovative technological training of teachers in the use of methodology of m-learning for a comfortable m-learning. Also, this training must be focused on customizable virtual environments so that, whether affinity for contents is low, the teacher can promote online tools previously tested as useful tools for the subject content, such as the visual tools for abstract or numerical contents [36,37] that are common in Accounting. It was demonstrated that visual tools in accounting learning can mobilize thought and reflection [79] and undergraduate accounting students find the use of visual tools offers them the necessary time, flexibility, and functionality in their reflections [80].

Although a positive association between satisfaction with online accounting learning and affinity for learning in VLE was found as in prior papers [41], the results of our research did not find a direct linear association between affinity for VLE and perceived utility of online tools. Affinity for learning in virtual environments plays an indirect explanatory relationship related to accounting affinity, being the self-perceptions on generic skills the moderating variable between the previous two. This finding indirectly corroborates that certain generic skills act as drivers in student's attitude towards accounting learning, such as analytical and numerical skills [35].

This research focused on the specific aspect of measuring the perceived utility of online tools in an m-learning environment and the effect of attitudinal and perceptions variables, making it difficult to compare the results with other research with different variables and method. However, this comparison can be used to show whether results point to the same general conclusions, which serves to define theoretical frameworks and variables. Detailed study of these variables for each environment might improve the sustainability of m-learning. The characteristics of each m-learning environment and the research objectives are linked to the practical applicability of the results to each learning environment. This partial comparability of results could be considered as a limitation of this work, although results offer valuable information for the design and improvement of m-learning environments.

Finally, considering the fit of the model ( $\mathrm{R}^{2}$ around $34 \%$ ), it must be concluded that although the accounting affinity and the perceived teacher's role favors the perceived utility of online tools in virtual learning environments, these variables are not the sole determinants of the perceived utility of 
online tools. Therefore, a future extension of this study would lead to the analysis of other explanatory variables of utility. In this sense, we share the idea of [19] that the success of m-learning may be due more to the method of use and context of use of technological tools rather than to the tools themselves. Furthermore, according to [39], in this context, the teacher plays a priority role in self-directed learning, bearing in mind that self-directed learning is considered essential for the sustainability of learning throughout life. This leads us to consider for future research the analysis of perceptions and attitudes in m-learning from the teacher's perspective (mobile teaching or mobile education). As the authors of [1] indicated, teachers need to be trained to incorporate online learning tools based on mobile devices, but technology and curriculum should also be integrated in order to ensure success in m-learning. We join the idea of [15] that indicates that, sometimes, the failure of new teaching technologies is because the teacher's attitude has not been considered for the methodological design of the teaching process. Experimental studies indicate the convenience of teacher's training in skills to teach [81], in order to improve the teaching planning. This idea could be extended to accounting teaching in m-learning. In line with what is pointed out by [82], students' demotivating attitudes should also be considered, but from the teacher's perspective. This approach would be useful to plan instruction, especially in subjects with a high numerical and abstract content.

Author Contributions: The authors contributed equally to this work. All the authors contributed to the conceptualization, formal analysis, investigation, methodology, writing of the original draft, and review and editing. All authors have read and agreed to the published version of the manuscript.

Funding: This research received no external funding.

Acknowledgments: The authors would like to thank all the referees for the time spent in this work, as well as the recommendations and suggestions made by them, which have contributed to the improvement of the paper. We would like to thank the University Institute of Distance Education (IUED) of the UNED, for the actions undertaken to promote research related to innovation, teaching and learning, through the competitive call for teaching innovation projects; as well as the Department of Business Economics and Accounting (UNED). This research was carried out as a part of a teaching innovation project called by IUED.

Conflicts of Interest: The authors declare no conflict of interest.

\section{Appendix A}

Table A1. Summary of items that make up each variable.

\begin{tabular}{ll}
\hline \multicolumn{1}{c}{ Self-perception of own general skills (GS_I) } \\
- & Resolve problems \\
- & Analytic skills \\
- & Team works \\
- & self-planning of work \\
- & Aealing with unknown problems \\
\hline & \\
\hline & Accounting is useful because it summarizes information numerically \\
- & Accounting is a profession with high employability \\
- & Accounting is more objective than subjective \\
- & Accounting is enjoyable \\
- & For any could choose the accounting profession for me. \\
- & Accounting is useful for studying other academic disciplines \\
- & Accounting helps explain the social role of companies in their environment \\
- & The study of accounting is useful for performance in the tourism sector \\
\hline
\end{tabular}


Table A1. Cont.

\section{Affinity to Virtual Learning Environment (VLE_I)}

- $\quad$ e-learning makes study easier

- I enjoy with mobile devices

- My experience with mobile devices helps online learning

- I usually use mobile devices

- I'm not intimidated by virtual learning environments

- I feel more comfortable in a virtual classroom

- $\quad$ e-learning enables self-directed learning

\section{Perception on the teacher's role (TCH_I)}

- $\quad$ The teacher encouraged my interest

- My interaction in the virtual environment was powered by the teacher

- The teacher helped me to solve my problems in the virtual environment

- I am relieved to feel that there is a teacher on the other side of the device

\section{Perceived utility of online learning tools (TOOLS_I)}

- $\quad$ The short zero course helped me to enter the study

- The forums helped me in my learning

- $\quad$ Forums mitigate my loneliness in learning

- Self-assessments are easy to use

- $\quad$ Self-assessments helped me in my learning

- $\quad$ Short videos helped me pinpoint important concepts easily

- Short videos are a convenient tool to use

- Short videos can replace the explanations of a face-to-face teacher

- Comics very graphically summarize important concepts

\section{References}

1. Papadakis, S. Evaluating pre-service teachers' acceptance of mobile devices with regards to their age and gender: A case study in Greece. IJMLO 2018, 12, 336-352. [CrossRef]

2. Grant, M.M. Difficulties in defining mobile learning: Analysis, design characteristics, and implications. Educ. Technol. Res. Dev. 2019, 67, 361-388. [CrossRef]

3. Keegan, D. A typology of distance teaching systems. In Distance Education: New Perspectives; Harry, K., Jon, M., Keegan, D., Eds.; Routledge: London, UK; New York, NY, USA, 1993; pp. 62-76.

4. Simonson, M.; Smaldino, S.; Albright, M.; Zvacek, S. Teaching and Learning at A Distance: Foundations of Distance, 3rd ed.; Pearson: Upper Saddle River, NJ, USA, 2006.

5. Cavus, N.; Bicen, H.; Akcil, U. The opinions of information technology students on using mobile learning. In Proceedings of the 08 International Conferences on Educational Sciences, Eastern Mediterranean University, Magosa, North Cyprus, 23-25 June 2008; Available online: https:/files.eric.ed.gov/fulltext/ED503539.pdf (accessed on 12 April 2020).

6. Richardson, J.; Lenarcic, J. Text Messaging as a Catalyst for Mobile Student Administration: The" Trigger" Experience. Int. J. Emerg. Technol. Soc. 2008, 6, 140-155.

7. Rodriguez, J.E. Social Media Use in Higher Education: Key Areas to Consider For Educators. Available online: https://our.oakland.edu/bitstream/handle/10323/2153/rodriguez_1211.pdf (accessed on 12 April 2020).

8. Traxler, J. Defining, discussing and evaluating mobile learning: The moving finger writes and having writ. Int. Rev. Res. Open Distrib. Learn. 2007, 8,1-12. [CrossRef]

9. Shin, N. Transactional presence as a critical predictor of success in distance learning. Distance Educ. 2003, 24, 69-86. [CrossRef] 
10. De la Fuente Sánchez, D.; Solís, M.H.; Martos, I.P. El mini video como recurso didáctico en el aprendizaje de materias cuantitativas. RIED. Revista Iberoamericana de Educación a Distancia 2013, 16, 177-192. [CrossRef]

11. Keirns, J.L. Designs for Self-Instruction. Principles, Processes, and Issues in Developing Self-Directed Learning; Allyn and Bacon: Needham Heights, MA, USA, 1999.

12. Palloff, R.M.; Pratt, K. Building Learning Communities in Cyberspace: Effective Strategies for the Online Classroom; Jossey Bass: San Francisco, CA, USA, 1999.

13. Kizilcec, R.F.; Halawa, S. Attrition and achievement gaps in online learning. In Proceedings of the Second (2015) ACM Conference on Learning@ Scale, Vancouver, BC, Canada, 14-18 March 2015; pp. 57-66.

14. Chen, P.D.; Lambert, A.D.; Guidry, K.R. Engaging online learners: The impact of web-based technology on college student engagement. Comput. Educ. 2010, 54, 1222-1232. [CrossRef]

15. Kalogiannakis, M.; Papadakis, S. Evaluating pre-service kindergarten teachers' intention to adopt and use tablets into teaching practice for natural sciences. Int. J. Mob. Learn. Organ. 2019, 13, 113-127. [CrossRef]

16. White, D.H.; Robertson, L. Implementing assistive technologies: A study on co-learning in the Canadian elementary school context. Comput. Hum. Behav. 2014. [CrossRef]

17. Williams, R.; Karousou, R.; Mackness, J. Emergent learning and learning ecologies in Web 2.0. Int. Rev. Res. Open Distrib. Learn. 2011,12,39-59. Available online: http://www.irrodl.org/index.php/irrodl/article/view/883 (accessed on 4 May 2020). [CrossRef]

18. Kim, R.H. Self-Directed Learning Management System: Enabling Competency and Self-Efficacy in Online Learning Environments. Ph.D. Thesis, The Claremont Graduate University, Claremont, CA, USA, 2010.

19. Unwin, A. The professionalism of the higher education teacher: What's ICT got to do with it? Teach. Higher Educ. 2007, 12, 295-308. [CrossRef]

20. Molnár, G. Digital instruction or the digitalization of instruction in modern ICT environment. Opus et Educatio 2019, 6. [CrossRef]

21. UNESCO Institute for Lifelong Learning. UNESCO Conference Report: Third International Conference on Learning Cities (ICLC); UNESCO Institute for Lifelong Learning: Hamburg, Germany, 2017.

22. Kamrozzaman, N.A.; Badusah, J.; Ruzanna, W.M. Development of heutagogy approach in M-learning for sustainability education. Educ. Inf. Technol. 2020, 1-13. [CrossRef]

23. Hossain, S.F.A.; Shan, X.; Nurunnabi, M. Is M-Learning a Challenge?: Students Attitudes Toward the Sustainable Learning and Performance. Int. J. e-Collab 2019, 15, 21-37. [CrossRef]

24. Ifenedo, E.; Rikala, J.; Hamalainen, T. Factors affecting Nigerian teacher educators' technology integration: Considering characteristics, knowledge constructs, ICT practices and beliefs. Comput. Educ. 2020, 146, 1-17. [CrossRef]

25. Moreno-Guerrero, A.J.; Rodríguez-Jiménez, C.; Gómez-García, G.; Ramos Navas-Parejo, M. Educational Innovation in Higher Education: Use of Role Playing and Educational Video in Future Teachers' Training. Sustainability 2020, 12, 2558. [CrossRef]

26. Moreno-Guerrero, A.J.; Romero-Rodríguez, J.M.; López-Belmonte, J.; Alonso-García, S. Flipped learning approach as educational innovation in water literacy. Water 2020, 12, 574. [CrossRef]

27. Ruangvanich, S.; Piriyasurawong, P. Structural Equation Model of Acceptance Cloud Learning for Sustainability Usage in Higher Education Institutes. Int. J. Emerg. Technol. Learn. 2019, 14, 18-33. [CrossRef]

28. Chen, C.L.; Wu, C.C. Students' behavioral intention to use and achievements in ICT-Integrated mathematics remedial instruction: Case study of a calculus course. Comput. Educ. 2020, 145, 103740. [CrossRef]

29. Bekoe, R.A.; Owusu, G.M.Y.; Ofori, C.G.; Essel-Anderson, A.; Welbeck, E.E. Attitudes towards accounting and intention to major in accounting: A logistic regression analysis. J. Account. Emerg. Econ. 2018, 8, 459-475. [CrossRef]

30. Jackling, B.; De Lange, P.; Phillips, J.; Sewell, J. Attitudes towards accounting: Differences between Australian and international students. Account. Res. J. 2012, 25, 113-130. [CrossRef]

31. Hutchins, R.; Roberts, D. Factors that Determine the Decision to Major in Accounting: A Survey of Accounting Graduates. Account. Educ. J. 2019, 28, 159-167.

32. Mastilak, C. First-Day Strategies for Millennial Students in Introductory Accounting Courses: It's All Fun and Games Until Something Gets Learned. J. Educ. Bus. 2012, 87, 48-51. [CrossRef]

33. Toerner, M.C. Sequencing Topics in Business-World Order: An Examination of Its Use as an Innovative Activity in Introductory Financial Accounting. J. Acad. Bus. Educ. 2012, 13, 122-136. 
34. Dangi, M.R.M.; Adnan, M.F.; Rashid, M.Z.A. An Innovation in Teaching and Learning of Accounting Concept Using AccRoBa@ Game Approach. J. Pendidik. Malays. 2017, 42, 21-32.

35. Phillips, M.E.; Graeff, T.R. Using an In-Class Simulation in the First Accounting Class: Moving From Surface to Deep Learning. J. Educ. Bus. 2014, 89, 241-247. [CrossRef]

36. Reynolds, G.; Grimley, M. Teaching first level tertiary accounting using a graphical method to improve students'understanding and engagement. People Int. J. Soc. Sci. 2019, 5. [CrossRef]

37. Tan, L.M.; Laswad, F. Students' beliefs, attitudes and intentions to major in accounting. Account. Educ. Int. J. 2006, 15, 167-187. [CrossRef]

38. Goh, E.; Scerri, M. "I study accounting because I have to": An exploratory study of hospitality students' attitudes toward accounting education. J. Hosp. Tour. Educ. 2016, 28, 85-94. [CrossRef]

39. Mladenovic, R. An investigation into ways of challenging introductory accounting students' negative perceptions of accounting. Account. Educ. 2000, 9, 135-155. [CrossRef]

40. Martins, L.L.; Kellermanns, F.W. A model of business school students' acceptance of a web-based course management system. Acad. Manag. Learn. Educ. 2004, 3, 7-26. [CrossRef]

41. Chen, C.C.; Jones, K.T. Blended learning vs. traditional classroom settings: Assessing effectiveness and student perceptions in an MBA accounting course. J. Educ. Online 2007, 4, n1.

42. Herrador-Alcaide, T.C.; Hernández-Solís, M.; Galván, R.S. Feelings of satisfaction in mature students of financial accounting in a virtual learning environment: An experience of measurement in higher education. Int. J. Educ. Technol. High. Educ. 2019, 16, 20. [CrossRef]

43. Kreijns, K.; Kirschner, P.; Jochems, W. Identifying the pitfalls for social interaction in computer-supported collaborative learning environments: A review of the research. Comput. Hum. Behav. 2003, 19, 335-353. [CrossRef]

44. Dickey, M. The impact of web-logs (blogs) on student perceptions of isolation and alienation in a web-based distance-learning environment. Open Learn. J. Open Distance e-Learn. 2004, 19, 279-291. [CrossRef]

45. Holder, B. An investigation of hope, academics, environment, and motivation as predictors of persistence in higher education online programs. Internet High. Educ. 2007, 10, 245-260. [CrossRef]

46. Grieve, R.; Padgett, C.R.; Moffitt, R.L. Assignments 2.0: The role of social presence and computer attitudes in student preferences for online versus offline marking. Internet High. Educ. 2016, 28, 8-16. [CrossRef]

47. McGrath, D.; Crowley, L.; Rao, S.; Toomey, M.; Hannigan, A.; Murphy, L.; Dunne, C.P. Outcomes of Irish graduate entry medical student engagement with self-directed learning of clinical skills. BMC Med. Educ. 2015, 15, 21. [CrossRef]

48. Sun, P.C.; Tsai, R.J.; Finger, G.; Chen, Y.Y.; Yeh, D. What drives a successful elearning? An empirical investigation of the critical factors influencing learner satisfaction. Comput. Educ. 2008, 50, 1183-1202. [CrossRef]

49. Soon, K.H.; Sook, K.I.; Jung, C.W.; Im, K.M. The effects of Internet-based distance learning in nursing. Comput. Nurs. 2000, 18, 19-25.

50. Levy, Y.; Ramim, M.M. The e-learning skills gap study: Initial results of skills desired for persistence and success in online engineering and computing courses. In Proceedings of the Chais 2017 Conference on Innovative and Learning Technologies Research, The Open University of Israel, Raanana, Israel; 2017; pp. 57E-68E. Available online: https://www.openu.ac.il/innovation/chais2017/a1_2.pdf (accessed on 13 March 2020).

51. Pritchard, A.; Woollard, J. Psychology for the Classroom: Constructivism and Social Learning; Taylor and Francis: London, UK, 2010.

52. Dillenbourg, P. Design for classroom orchestration. Comput. Educ. 2013, 69, 485-492. [CrossRef]

53. Dimitriadis, Y.; Prieto, L.P.; Asensio-Perez, J.I. The role of design and enactment patterns in orchestration: Helping to integrate technology in blended classroom ecosystems. Comput. Educ. 2013, 69, 496-499. [CrossRef]

54. Anderson, T.; Liam, R.; Garrison, D.R.; Archer, W. Assessing teaching presence in a computer conferencing context. J. Asynchcronous Learn. Netw. (JALN) 2001, 5, 1-17. [CrossRef]

55. Rourke, L.; Anderson, T. Exploring social communication in computer conferencing. J. Interact. Learn. Res. 2002, 13, 259-275.

56. İlin, G. Sustainability in Lifelong Learning: Learners' Perceptions from a Turkish Distance Language Education Context. Sustainability. 2019, 11, 5284. [CrossRef] 
57. Byrne, M.; Flood, B. Assessing the teaching quality of accounting programmes: An evaluation of the Course Experience Questionnaire. Assess. Eval. High. Educ. 2003, 28, 135-145. [CrossRef]

58. Herrador-Alcaide, T.C.; Hernández-Solís, M. Educación Digital Contable mediante Redes de Innovación: Una Medición de su Impacto. Digit. Educ. Rev. 2016, 29, 247-264.

59. Alsadoon, H. Students' perceptions of E-assessment at Saudi Electronic University. Turk. Online J. Educ. Technol. 2017, 16, 147-153.

60. Silva, R.; Rodrigues, R.; Leal, C. Play it again: How game-based learning improves flow in Accounting and Marketing education. Account. Educ. 2019, 28, 484-507. [CrossRef]

61. Van Wyk, M.M. Exploring student teachers' views on e-portfolios as an empowering tool to enhance self-directed learning in an online teacher education course. Aust. J. Teach. Educ. 2017, 42, 1. [CrossRef]

62. Johnston, J.; Killion, J.; Oomen, J. Student satisfaction in the virtual classroom. Internet J. Allied Health Sci. Pract. 2005, 3, 6.

63. Brecht, H.D.; Ogilby, S.M. Enabling a comprehensive teaching strategy: Video lectures. J. Inf. Technol. Educ. 2008, 7, 71-86.

64. Chang, C.T.; Hajiyev, J.; Su, C.R. Examining the students' behavioral intention to use e-learning in Azerbaijan? The general extended technology acceptance model for e-learning approach. Comput. Educ. 2017, 111, 128-143. [CrossRef]

65. Chen, I.Y.; Chen, N.S.; Kinshuk. Examining the factors influencing participants' knowledge sharing behavior in virtual learning communities. J. Educ. Technol. Soc. 2009, 12, 134.

66. Zhan, X.; Sun, D.; Qiang, C.; Song, R.; Wan, Z.H. Propensity Score Analysis of the Impacts of Junior Secondary Students' Participation in Engineering Practices on their Attitudes toward Engineering. EURASIA J. Math. Sci. Technol. Educ. 2019, 15, 11.

67. Keles, Ö. Investigation of Pre-Service Science Teachers' Attitudes towards Sustainable Environmental Education. High. Educ. Stud. 2017, 7, 171-180. [CrossRef]

68. Al-Qahtani, M.F. Measuring healthcare students' attitudes toward interprofessional education. J. Taibah Univ. Med. Sci. 2016, 11, 579-585. [CrossRef]

69. Ahinful, G.S.; Tauringana, V.; Bansah, E.A.; Essuman, D. Determinants of academic performance of accounting students in Ghanaian secondary and tertiary education institutions. Account. Educ. 2019, 28, 553-581. [CrossRef]

70. Bailey, C.D. Psychopathy and accounting students' attitudes towards unethical professional practices. J. Account. Educ. 2017, 41, 15-32. [CrossRef]

71. Su, S.; Baird, K. The impact of collegiality amongst Australian accounting academics on work-related attitudes and academic performance. Stud. High. Educ. 2017, 42, 411-427. [CrossRef]

72. Prior, D.D.; Mazanov, J.; Meacheam, D.; Heaslip, G.; Hanson, J. Attitude, digital literacy and self efficacy: Flow-on effects for online learning behavior. Internet High. Educ. 2016, 29, 91-97. [CrossRef]

73. Kintu, M.J.; Zhu, C.; Kagambe, E. Blended learning effectiveness: The relationship between student characteristics, design features and outcomes. Int. J. Educ. Technol. High. Educ. 2017, 14, 7. [CrossRef]

74. Wasserman, E.; Migdal, R. Professional Development: Teachers' Attitudes in Online and Traditional Training Courses. Online Learn. 2019, 23, 132-143. [CrossRef]

75. Tan, P.J.B. An empirical study of how the learning attitudes of college students toward English e-tutoring websites affect site sustainability. Sustainability 2019, 11, 1748. [CrossRef]

76. Lin, S.H.; Huang, Y.C. The Effect of Teacher Charisma on Student Attitude towards Calculus Learning. Sci. Technol. Soc. 2017, 5, 26-32. [CrossRef]

77. Winardi, R.D.; Azalea, M. Why do accounting students at higher learning institutions conduct an academic dishonesty? In SHS Web of Conferences; EDP Sciences, 2017; Volume 34, Available online: https:/www.shsconferences.org/articles/shsconf/pdf/2017/02/shsconf_four2017_06008.pdf (accessed on 12 April 2020).

78. Delaney, D.; Kummer, T.F.; Singh, K. Evaluating the impact of online discussion boards on student engagement with group work. Br. J. Educ. Technol. 2019, 50, 902-920. [CrossRef]

79. Marriott, P.; McGuigan, N. Visual metaphor and visual tools in accounting education. Account. Educ. 2018, 27, 549-551. [CrossRef]

80. Osgerby, J.; Marriott, P.; Gee, M. Accounting students perceptions of using visual metaphor as part of personal development planning: An exploratory case study. Account. Educ. 2018, 27, 570-589. [CrossRef] 
81. Trudel, L.; Métioui, A. Study of the implantation of an experiential approach to science teachers' training in Francophone minority communities: Results from the second phase of a three phases design research. J. Phys. Conf. Ser. 2019, 1286, 012043. [CrossRef]

82. Ricoy, M.-C.; Couto, M.J. Desmotivación del alumnado de secundaria en la materia de matemáticas. Rev. Electrón. Investig. Educ. 2018, 20, 69-79. [CrossRef]

(C) 2020 by the authors. Licensee MDPI, Basel, Switzerland. This article is an open access article distributed under the terms and conditions of the Creative Commons Attribution (CC BY) license (http://creativecommons.org/licenses/by/4.0/). 